\title{
Adapting the SCOR model for supply chain network assessment and improvement in oil industry
}

\author{
Daryosh Mohammadi Janaki ${ }^{\mathrm{a}^{*}}$
}

\begin{tabular}{l} 
a Department of Industrial Engineering \\
\hline C H R O N I C L E \\
\hline Article history: \\
Received: January 30, 2019 \\
Received in revised format: April \\
20, 2019 \\
Accepted: April 22, 2019 \\
Available online: \\
April 25, 2019 \\
\hline Keywords: \\
Supply Chain Network \\
Uncertainty \\
Network DEA \\
\end{tabular}

\section{Kharazmi University Tehran, Iran A B S T R A C T}

\begin{abstract}
Supply chain management in oil and gas industry plays an important role for the success of these companies in most countries. A reliable supply chain helps on time delivery of goods and services and leads to better performance of the firms and yields higher profitability. This paper presents an empirical investigation to measure the relative efficiency of different oil distribution companies in Iran. The proposed study uses a five-stage Supply-Chain Operations Reference (SCOR) technique to measure the relative efficiencies of 40 distribution oil companies. The study designs a questionnaire based on four balanced scorecard perspectives and distributes it among various experts who were familiar with supply chain issues. The results indicate that the network performed relatively efficient since the study did not detect any unit with low performance and most of them maintained relatively high scores.
\end{abstract}

\section{Introduction}

Nowadays, organizations continuously use methods and techniques to improve the performance of their organizations. Supply chain management is able to meet some certain conditions as an integrated approach for managing the flow of materials and goods (Beamon, 1999). Performance measurement is defined as a quantitative process, or more precisely, a process used for the analysis of efficiency and productivity (Gunasekaran \& Ngai, 2004). According to this definition, the efficiency of the supply chain is defined as a measure of the performance measurement of the company's resources in the overall context of the supply chain in order to achieve its specific goals. Iranian oil products distribution industry has a large number of suppliers and customers as a national industry. A need for comprehensive and integrated solutions is felt for the country's oil products distribution industry and making a suitable context with approaching the domestic supply level to demand, global trade, import and export of oil products in the country, and increasing the variety of products. Measuring the performance of the supply chain in oil industry plays an important role for the success of these companies. Data Envelopment Analysis is believed to be one of the well-known methods for measuring the relative efficiencies of similar unites (Charnes et al., 1984, 2013). During the past three decades, DEA has been developed in different forms 
and one of the popular ones is associated with the Supply-Chain Operations Reference (SCOR) (Georgise et al., 2012). According to Ntabe et al. (2015), SCOR is a suitable method for analyzing green supply chain management and it a diagnostic tool for supply chains, which can serve as a strategic tool for such environmental performance. However, the SCOR has its own limits to measure the supply chain performance, the first limitation is associated with the large number of individual measurements used in the field of supply chain. It has proven that for participants in the supply chain and effective management of a supply chain could be a very effective mechanism for fast and reliable delivery of high quality goods and services with a minimum cost (Piotrowicz \& Cuthbertson, 2015). Efficiency in large set of organizations based on the SCOR reference model with a dynamic system approach is considered as one of the most important and vital management activities with a lot of competitive advantages to the county's oil products industry in addition to the chain arrangement. It has shown that effective management of a supply chain refers to a very effective mechanism for delivering fast and reliable high quality goods and services with a minimum cost (Jagadesh, 2015).

Gunasekaran and Ngai (2004) stated that when developing the supply chain through information technology we see the lack of integration between information technology and the business model of the organization, the lack of proper strategic planning, the poor infrastructures for information technology infrastructure, the inadequate and the incorrect use of information technology in virtual enterprises and the lack of adequate knowledge about the implementation of information technology. In the past, marketing, distribution, planning, production, and sales companies acted in an independent supply chain. Some researchers evaluated the performance of independent units of a supply chain, such as distribution centers performance (Ross \& Droge 2002), sales performance measurement (Estampe et al,, 2013), measurement of supplier performance (Talluri et al., 2006), etc. However, these independent entities in the supply chain have their own specific goals, and often these goals are in conflict with each other. Therefore, a need for a performance measurement framework is felt, so that the performance of these independent units can be integrated and evaluated in this framework simultaneously (Mohamadi Janaki et al., 2019; Battese \& Coelli, 1995).

The performance measurement of the entire supply chain is very important in order to achieve an efficient supply chain. These approaches seek to minimize system costs while a certain level of service can be satisfied by these approaches. Supply chain management, which is increasingly developing, refers to integrating organizational units within the chain and creating coordination in the flows of materials, information and financial resources aimed to meet the customers' needs and achieve a reliable and longterm competitive advantage. The SCOR model is considered as the first overall framework for supply chain management and performance measurement and improvement, and the first model that can be used to shape supply chain based on business strategy (Aydin et al., 2014). This model provides a standard and comprehensive model, and being process oriented is the main advantage of the performance measurement compared with the previous models. Therefore, this process-oriented view provides a hierarchical and structured construct of evaluations and criteria that provides an overview of the supply chain to all supply chain executives (Ntabe et al., 2015). The model provides a common framework, common terms, common parameters, superior techniques, and also expresses a hierarchical structure with different levels. The basic hierarchical composition of the SCOR model is as follows (Georgise et al., 2012).

Level 1: Types of Process: It defines domain and content using 5 types of process: Plan, Prohibition, Make, Deliver, and Return.

Level 2: Process classifications: This level defines the level of configuration, where a supply chain can be defined using the main process classes.

Level 3: Process activities: This level divides processes into process elements, explains inputs and outputs, process performance criteria, and identifies the best activities. 


\section{Research methodology}

The purpose of this study is to measure the supply chain performance of the oil products distribution company in Chaharmahal and Bakhtiari province of Iran using information sharing indices. Therefore the study is considered as an applied research in terms of the objective and in terms of data collection method is considered as a research study, descriptive-survey. In this study, in order to collect information, the views of 240 managers and experts who were aware of the issue of supply chain in each department have been used separately in Oil Distribution Companies located in cities of Chaharmahal and Bakhtiari, Kohgiluyeh and Boyer Ahmad, Tehran, Isfahan. Data collection method in the present study includes library studies and field studies in form of interview and questionnaire. In order to achieve appropriate validity for the questionnaire, in the initial design of questions, the items such as structure of the questionnaire, understandable sentences were used. After initial design of the questionnaires, the opinions of the supervisors, consultants and experts were used in order to increase the validity. Cronbach's alpha coefficient test was used to test the reliability of the questionnaire. The obtained alpha is 0.754 which shows the suitable reliability of the questionnaire.

\subsection{Identification of Performance Measurement Indicators in the Supply Chain}

In Table 1, the information technology (IT) indicators are classified in terms of balanced score card perspectives (Kaplan \& Norton, 2001; Kaplan et al., 2001); namely financial, customer, internal processes, growth and learning in a supply chain.

\section{Table 1}

Supply Chain Performance Measurement Indicators Using the SCOR Model

\begin{tabular}{|c|c|c|}
\hline Variables & Row & Indicators \\
\hline \multirow{4}{*}{$\begin{array}{l}\text { Designing and } \\
\text { Planning }\end{array}$} & 1 input & How much does the price index affect in the field of design and planning? \\
\hline & 2 inputs & What is the total cost of data transfer in the design and planning of the company? \\
\hline & 3 Outputs & How much does the total supply chain response time affect in the field of design and planning? \\
\hline & 4 inputs & How much does customer response time in design and planning? \\
\hline \multirow[t]{4}{*}{$\begin{array}{l}\text { Supply and } \\
\text { Sourcing }\end{array}$} & 5 Inputs & $\begin{array}{l}\text { How much is the level of supplier and buyer participation in the company in the field of supply and sourc- } \\
\text { ing? }\end{array}$ \\
\hline & 6 Inputs & $\begin{array}{l}\text { How much is the level of accuracy and timeliness are the information in the field of supply and sourcing of } \\
\text { the company, }\end{array}$ \\
\hline & 7 Inputs & What is the suitable level of product quality in the company in the field of supply and sourcing? \\
\hline & 8 Outputs & How much is the company's scheduled delivery time compared to the industry's soft in the field of supply? \\
\hline \multirow{3}{*}{$\begin{array}{l}\text { Production and } \\
\quad \text { Make }\end{array}$} & 9 inputs & What is the level of accuracy in inventory information in the field of making and production? \\
\hline & 10 inputs & How is flexibility in the field of production? \\
\hline & 11 Outputs & What is the inventory capacity in the field of making and production? \\
\hline \multirow{3}{*}{$\begin{array}{l}\text { Send and } \\
\text { Deliver }\end{array}$} & 12 Reverse / Inputs & How much is the shipping costs per unit in the field of sending and delivery? \\
\hline & 13 inputs & In terms of send and delivery of the company, how much is the transportation efficiency indicator? \\
\hline & 14 Outputs & In the field of sending and deliver, How is reliability of sending the goods to the company? \\
\hline \multirow[t]{5}{*}{ Returning } & 15 inputs & The quality of the goods is checked at what level in the field of returning? \\
\hline & 16 Outputs & How much flexibility has been respected in the service delivery system to a specific need? \\
\hline & 17 inputs & Response time in the supply chain \\
\hline & 18 Outputs & How satisfied are customer satisfaction indicators in the field of returning? \\
\hline & 19 Outputs & How much is the total cost of the company in the returning field? \\
\hline
\end{tabular}

\subsection{Solution procedure}

The conceptual model of SCOR is presented as follows:

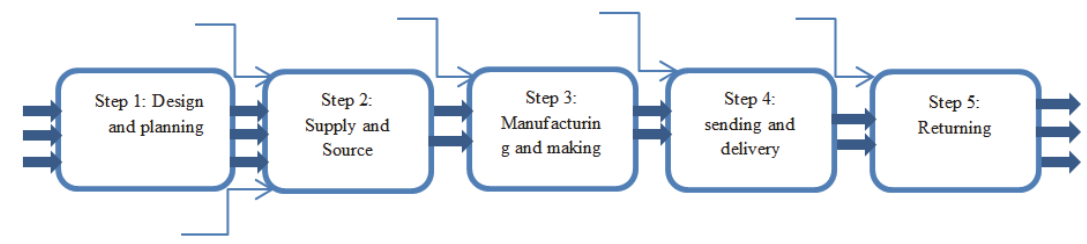

Fig. 1. SCOR conceptual model in the form of a multi-stage system which each stage has input and output performance indicators 
The model for the SCOR model performance measurement of DEA is developed as shown in Fig. 2/

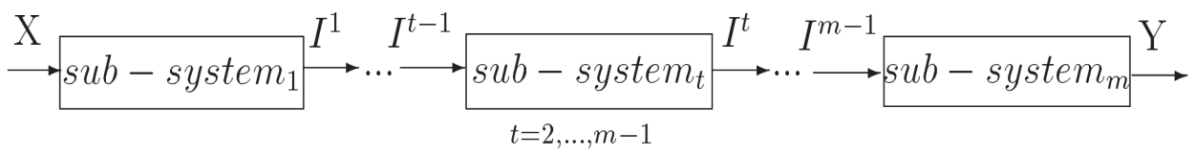

Fig. 2. Network Data Envelopment Analysis for SCOR Measurement

\section{DEA model results}

The values of the calculated efficiency at each stage and the total efficiency for 40 decision-making units are shown in Table 2. At first, according to table, a questionnaire was designed and distributed amongst 1200 cases of managers and experts (quality control section - planning section -warehouse section - inspection section-management section-CNG section) of these companies. These 1200 experts were the managers who not only have some information but also they were familiar with the company's strategy and only these people could respond the questionnaire professionally, So we considered the average of these qualitative numbers for inputs and outputs.

Table 2

Average Quality Kits of completed questionnaires of oil distribution companies

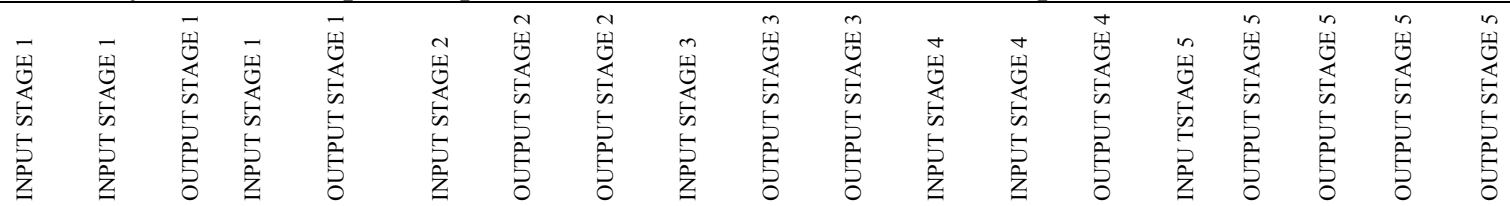

\begin{tabular}{|c|c|c|c|c|c|c|c|c|c|c|c|c|c|c|c|c|c|c|c|}
\hline$\overline{\mathrm{DMU}}$ & 1 & 2 & 3 & 4 & 5 & 6 & 7 & 8 & 9 & 10 & 11 & 12 & 13 & 14 & 15 & 16 & 17 & 18 & 19 \\
\hline 1 & 5 & 2 & 4 & 4 & 4 & 4 & 3 & 3 & 4 & 4 & 4 & 4 & 3 & 5 & 5 & 4 & 3 & 4 & 2 \\
\hline 2 & 5 & 4 & 4 & 4 & 5 & 4 & 5 & 5 & 4 & 5 & 5 & 4 & 5 & 4 & 4 & 3 & 4 & 4 & 4 \\
\hline 3 & 3 & 3 & 3 & 4 & 2 & 2 & 3 & 4 & 2 & 2 & 2 & 3 & 4 & 3 & 3 & 3 & 4 & 4 & 3 \\
\hline 4 & 5 & 4 & 4 & 4 & 4 & 5 & 4 & 3 & 3 & 3 & 2 & 5 & 4 & 3 & 4 & 5 & 5 & 4 & 4 \\
\hline 5 & 5 & 4 & 4 & 4 & 4 & 4 & 3 & 4 & 3 & 4 & 3 & 3 & 4 & 4 & 3 & 3 & 4 & 4 & 4 \\
\hline 6 & 5 & 4 & 4 & 3 & 4 & 4 & 4 & 2 & 4 & 4 & 3 & 4 & 4 & 4 & 4 & 4 & 4 & 4 & 4 \\
\hline 7 & 5 & 3 & 4 & 3 & 4 & 3 & 4 & 2 & 5 & 3 & 4 & 4 & 4 & 3 & 4 & 4 & 4 & 5 & 2 \\
\hline 8 & 4 & 4 & 4 & 4 & 3 & 4 & 4 & 3 & 4 & 4 & 3 & 3 & 4 & 4 & 5 & 4 & 5 & 3 & 4 \\
\hline 9 & 4 & 4 & 2 & 4 & 2 & 2 & 4 & 4 & 3 & 3 & 4 & 4 & 4 & 4 & 5 & 4 & 3 & 4 & 4 \\
\hline 10 & 4 & 3 & 4 & 3 & 5 & 4 & 4 & 3 & 2 & 3 & 4 & 3 & 4 & 4 & 5 & 5 & 3 & 3 & 3 \\
\hline 11 & 1 & 3 & 3 & 4 & 3 & 4 & 3 & 3 & 3 & 4 & 4 & 3 & 4 & 4 & 4 & 4 & 3 & 3 & 3 \\
\hline 12 & 4 & 4 & 3 & 4 & 4 & 4 & 4 & 3 & 4 & 3 & 2 & 3 & 4 & 4 & 3 & 3 & 3 & 4 & 4 \\
\hline 13 & 4 & 3 & 4 & 4 & 3 & 4 & 4 & 4 & 4 & 4 & 4 & 3 & 3 & 4 & 4 & 4 & 4 & 3 & 3 \\
\hline 14 & 5 & 3 & 5 & 4 & 4 & 3 & 4 & 2 & 4 & 4 & 4 & 3 & 2 & 5 & 3 & 4 & 5 & 3 & 3 \\
\hline 15 & 5 & 3 & 5 & 5 & 4 & & 4 & 3 & 4 & 3 & 4 & 3 & 3 & 4 & 5 & 2 & 2 & 4 & 3 \\
\hline 16 & 5 & 3 & 5 & 4 & 4 & 4 & 4 & 5 & 4 & 2 & 4 & 3 & 5 & 3 & 4 & 4 & 3 & 4 & 3 \\
\hline 17 & 3 & 4 & 3 & 3 & 4 & 4 & 4 & 3 & 3 & 4 & 2 & 3 & 3 & 4 & 4 & 3 & 3 & 2 & 4 \\
\hline 18 & 4 & 4 & 4 & 4 & 4 & 4 & 4 & 2 & 4 & 4 & 3 & 3 & 3 & 2 & 4 & 4 & 3 & 2 & 4 \\
\hline 19 & 5 & 5 & 4 & 4 & 4 & 4 & 3 & 3 & 4 & 4 & 4 & 3 & 3 & 5 & 3 & 3 & 3 & 5 & 5 \\
\hline 20 & 4 & 3 & 4 & 3 & 4 & 4 & 4 & 4 & 3 & 4 & 3 & 3 & 3 & 5 & 4 & 4 & 3 & 3 & 3 \\
\hline 21 & 4 & 3 & 4 & 5 & 2 & 4 & 3 & 3 & 4 & 3 & 3 & 3 & 3 & 5 & 4 & 4 & 2 & 3 & 3 \\
\hline 22 & 4 & 3 & 3 & 5 & 3 & 4 & 4 & 3 & 3 & 3 & 4 & 3 & 4 & 3 & 3 & 4 & 5 & 3 & 2 \\
\hline 23 & 4 & 3 & 5 & 4 & 3 & 5 & 2 & 3 & 2 & 2 & 4 & 3 & 2 & 4 & 4 & 3 & 5 & 2 & 3 \\
\hline 24 & 4 & 4 & 5 & 5 & 4 & 4 & 4 & 3 & 4 & 3 & 3 & 4 & 2 & 3 & 3 & 4 & 3 & 5 & 4 \\
\hline 25 & 4 & 2 & 5 & 4 & 2 & 4 & 4 & 4 & 5 & 5 & 4 & 3 & 5 & 5 & 3 & 3 & 5 & 4 & 2 \\
\hline 26 & 5 & 4 & 4 & 5 & 3 & 4 & 2 & 3 & 4 & 4 & 3 & 5 & 3 & 4 & 4 & 3 & 4 & 4 & 4 \\
\hline 27 & 4 & 3 & 3 & 2 & 2 & 4 & 4 & 2 & 3 & 3 & 4 & 3 & 3 & 4 & 4 & 4 & 4 & 4 & 3 \\
\hline 28 & 4 & 2 & 4 & 3 & 4 & 5 & 5 & 3 & 4 & 4 & 3 & 4 & 3 & 4 & 4 & 3 & 5 & 4 & 2 \\
\hline 29 & 4 & 4 & 5 & 5 & 3 & 4 & 3 & 2 & 4 & 3 & 4 & 3 & 3 & 4 & 4 & 4 & 4 & 4 & 4 \\
\hline 30 & 4 & 3 & 4 & 5 & 4 & 4 & 3 & 3 & 4 & 3 & 3 & 3 & 4 & 4 & 4 & 4 & 3 & 4 & 3 \\
\hline 31 & 3 & 2 & 4 & 4 & 3 & 5 & 3 & 4 & 4 & 2 & 3 & 4 & 3 & 4 & 4 & 3 & 3 & 5 & 2 \\
\hline 32 & 3 & 3 & 5 & 4 & 4 & 4 & 4 & 3 & 3 & 4 & 3 & 3 & 3 & 5 & 4 & 4 & 3 & 4 & 3 \\
\hline 33 & 3 & 3 & 4 & 3 & 2 & 4 & 3 & 3 & 4 & 4 & 4 & 3 & 4 & 3 & 4 & 3 & 3 & 4 & 3 \\
\hline 34 & 4 & 3 & 4 & 4 & 4 & 4 & 4 & 3 & 4 & 4 & 3 & 3 & 3 & 4 & 4 & 4 & 3 & 4 & 3 \\
\hline 35 & 3 & 2 & 5 & 3 & 4 & 4 & 5 & 3 & 4 & 4 & 2 & 3 & 3 & 4 & 4 & 4 & 5 & 4 & 2 \\
\hline 36 & 3 & 4 & 4 & 4 & 5 & 4 & 4 & 3 & 4 & 4 & 3 & 4 & 3 & 4 & 3 & 3 & 4 & 4 & 4 \\
\hline 37 & 4 & 3 & 5 & 4 & 4 & 4 & 4 & 4 & 4 & 3 & 3 & 4 & 3 & 4 & 3 & 4 & 3 & 4 & 3 \\
\hline 38 & 5 & 4 & 5 & 3 & 4 & 3 & 3 & 5 & 4 & 4 & 4 & 4 & 3 & 5 & 5 & 3 & 5 & 4 & 5 \\
\hline 39 & 5 & 3 & 4 & 4 & 2 & 4 & 4 & 4 & 3 & 4 & 3 & 3 & 3 & 4 & 3 & 4 & 3 & 5 & 3 \\
\hline 40 & 3 & 4 & 3 & 4 & 3 & 3 & 4 & 3 & 3 & 3 & 3 & 3 & 3 & 3 & 3 & 3 & 3 & 4 & 4 \\
\hline
\end{tabular}

Oil Products Distribution: (Chaharmahal va Bakhtiari: DMU1 - Tehran: DMU2- Kohgiluyeh and Boyer Ahmad: DMU3- Isfahan: DMU4- Lordgan: DMU5- Borujen: DMU6Shahrekord: DMU7- Yasuj: DMU8- Gachsaran: DMU9- Dehdasht : DMU10- Isfahan: DMU11- Kashan: DMU12- Fereydunshahr: DMU13- KhomeiniShahr: DMU14- Najaf Abad: DMU15- Shahin Shahr: DMU16- Shahreza: DMU17- Khorasgan: DMU18- Foulad Shahr: DMU19- Mobarakeh: DMU20- Baharestan: DMU21 - Zarin Shahr: DMU22Tiran: DMU23- Golpayegan: DMU24- Falavarjan: DMU25- Aran and Bidgol: DMU26- Tehran: DMU27- Nasim Shahr: DMU28- Golestan: DMU29- Ghods: DMU30- Malard: DMU31- Varamin: DMU32- Shahriar : DMU33 - Pakdasht: DMU34 - Ray: DMU35 - Robat Karim: DMU36 - Pardis: DMU37 - Andisheh: DMU38 - Gharchak: DMU39 - Islam Shahr: DMU40). 
Table 3 presents details of the implementation of DEA-SCOR model using 40 different units. As we can observe from the results of the table, most units were relatively efficient. In our survey, Tehran central unit has received the highest efficiency followed by Islam Shahr unit. The lowest efficiency belongs to Lordegan followed by Shariar.

Table 3

Calculation of Supply Chain Performance of Oil Products Distribution Companies by Using the DEASCOR Model

\begin{tabular}{|c|c|c|c|c|c|c|}
\hline $\begin{array}{c}\text { Decision } \\
\text { making unit }\end{array}$ & $\begin{array}{cc}\begin{array}{c}\text { Performance } \\
\text { stage }\end{array} & \\
\end{array}$ & $\begin{array}{l}\text { Performance } \\
\text { second stage }\end{array}$ & $\begin{array}{c}\text { Performance third } \\
\text { stage }\end{array}$ & $\begin{array}{l}\text { Performance } \\
\text { Stage Four }\end{array}$ & $\begin{array}{c}\begin{array}{c}\text { Performance fifth } \\
\text { stage }\end{array} \\
\end{array}$ & $\begin{array}{c}\text { Performance } \\
\text { Total }\end{array}$ \\
\hline $\mathrm{DMU}_{1}$ & 1 & 0.929 & 0.962 & 0.995 & 0.752 & 0.872 \\
\hline $\mathrm{DMU}_{2}$ & 0.847 & 1 & 0.957 & 0.799 & 1 & 0.893 \\
\hline $\mathrm{DMU}_{3}$ & 0.831 & 1 & 1 & 0.935 & 0.766 & 0.822 \\
\hline $\mathrm{DMU}_{4}$ & 1 & 0.913 & 0.958 & 0.846 & 1 & 0.888 \\
\hline $\mathrm{DMU}_{5}$ & 0.84 & 0.944 & 1 & 0.928 & 0.752 & 0.811 \\
\hline $\mathrm{DMU}_{6}$ & 1 & 0.951 & 1 & 0.814 & 0.827 & 0.858 \\
\hline $\mathrm{DMU}_{7}$ & 0.937 & 0.827 & 0.98 & 0.889 & 0.851 & 0.869 \\
\hline $\mathrm{DMU}_{8}$ & 1 & 0.943 & 0.913 & 1 & 0.8 & 0.879 \\
\hline $\mathrm{DMU}_{9}$ & 0.859 & 0.928 & 1 & 0.972 & 0.708 & 0.84 \\
\hline $\mathrm{DMU}_{10}$ & 1 & 1 & 0.945 & 0.942 & 0.731 & 0.858 \\
\hline $\mathrm{DMU}_{11}$ & 1 & 0.915 & 1 & 0.949 & 0.745 & 0.876 \\
\hline $\mathrm{DMU}_{12}$ & 0.989 & 1 & 0.908 & 0.912 & 0.827 & 0.855 \\
\hline $\mathrm{DMU}_{13}$ & 1 & 0.897 & 0.913 & 0.992 & 0.745 & 0.867 \\
\hline $\mathrm{DMU}_{14}$ & 1 & 0.919 & 0.974 & 0.979 & 0.763 & 0.867 \\
\hline $\mathrm{DMU}_{15}$ & 1 & 1 & 0.811 & 1 & 0.736 & 0.872 \\
\hline $\mathrm{DMU}_{16}$ & 0.976 & 0.933 & 1 & 0.871 & 0.785 & 0.855 \\
\hline $\mathrm{DMU}_{17}$ & 0.989 & 0.917 & 0.987 & 0.852 & 0.809 & 0.852 \\
\hline $\mathrm{DMU}_{18}$ & 1 & 0.924 & 0.975 & 0.859 & 0.806 & 0.88 \\
\hline $\mathrm{DMU}_{19}$ & 0.917 & 0.911 & 1 & 0.82 & 0.841 & 0.848 \\
\hline $\mathrm{DMU}_{20}$ & 0.958 & 0.905 & 0.929 & 1 & 0.683 & 0.841 \\
\hline $\mathrm{DMU}_{21}$ & 0.953 & 0.897 & 0.947 & 1 & 0.644 & 0.848 \\
\hline $\mathrm{DMU}_{22}$ & 1 & 1 & 1 & 0.847 & 1 & 0.869 \\
\hline $\mathrm{DMU}_{23}$ & 1 & 1 & 0.889 & 1 & 0.764 & 0.833 \\
\hline $\mathrm{DMU}_{24}$ & 0.999 & 0.86 & 0.939 & 0.809 & 0.834 & 0.854 \\
\hline $\mathrm{DMU}_{25}$ & 1 & 0.982 & 0.971 & 0.881 & 1 & 0.895 \\
\hline $\mathrm{DMU}_{26}$ & 1 & 1 & 0.912 & 0.872 & 0.785 & 0.87 \\
\hline $\mathrm{DMU}_{27}$ & 1 & 0.951 & 0.892 & 0.949 & 0.825 & 0.868 \\
\hline $\mathrm{DMU}_{28}$ & 1 & 0.865 & 0.992 & 0.999 & 0.733 & 0.861 \\
\hline $\mathrm{DMU}_{29}$ & 1 & 0.88 & 0.915 & 0.81 & 0.899 & 0.869 \\
\hline $\mathrm{DMU}_{30}$ & 1 & 0.816 & 1 & 1 & 0.825 & 0.87 \\
\hline $\mathrm{DMU}_{31}$ & 0.988 & 0.884 & 0.97 & 0.877 & 0.825 & 0.866 \\
\hline $\mathrm{DMU}_{32}$ & 1 & 0.935 & 1 & 0.921 & 0.785 & 0.852 \\
\hline $\mathrm{DMU}_{33}$ & 0.773 & 1 & 0.989 & 0.936 & 0.843 & 0.817 \\
\hline $\mathrm{DMU}_{34}$ & 0.941 & 0.952 & 0.899 & 0.986 & 0.79 & 0.844 \\
\hline $\mathrm{DMU}_{35}$ & 1 & 0.814 & 0.931 & 1 & 0.825 & 0.858 \\
\hline $\mathrm{DMU}_{36}$ & 0.967 & 0.988 & 0.959 & 1 & 0.756 & 0.851 \\
\hline $\mathrm{DMU}_{37}$ & 1 & 0.889 & 0.959 & 0.993 & 0.783 & 0.866 \\
\hline $\mathrm{DMU}_{38}$ & 1 & 0.879 & 0.94 & 1 & 0.913 & 0.87 \\
\hline $\mathrm{DMU}_{39}$ & 0.959 & 0.866 & 0.962 & 0.991 & 0.759 & 0.849 \\
\hline $\mathrm{DMU}_{40}$ & 1 & 0.962 & 1 & 0.866 & 0.952 & 0.887 \\
\hline
\end{tabular}




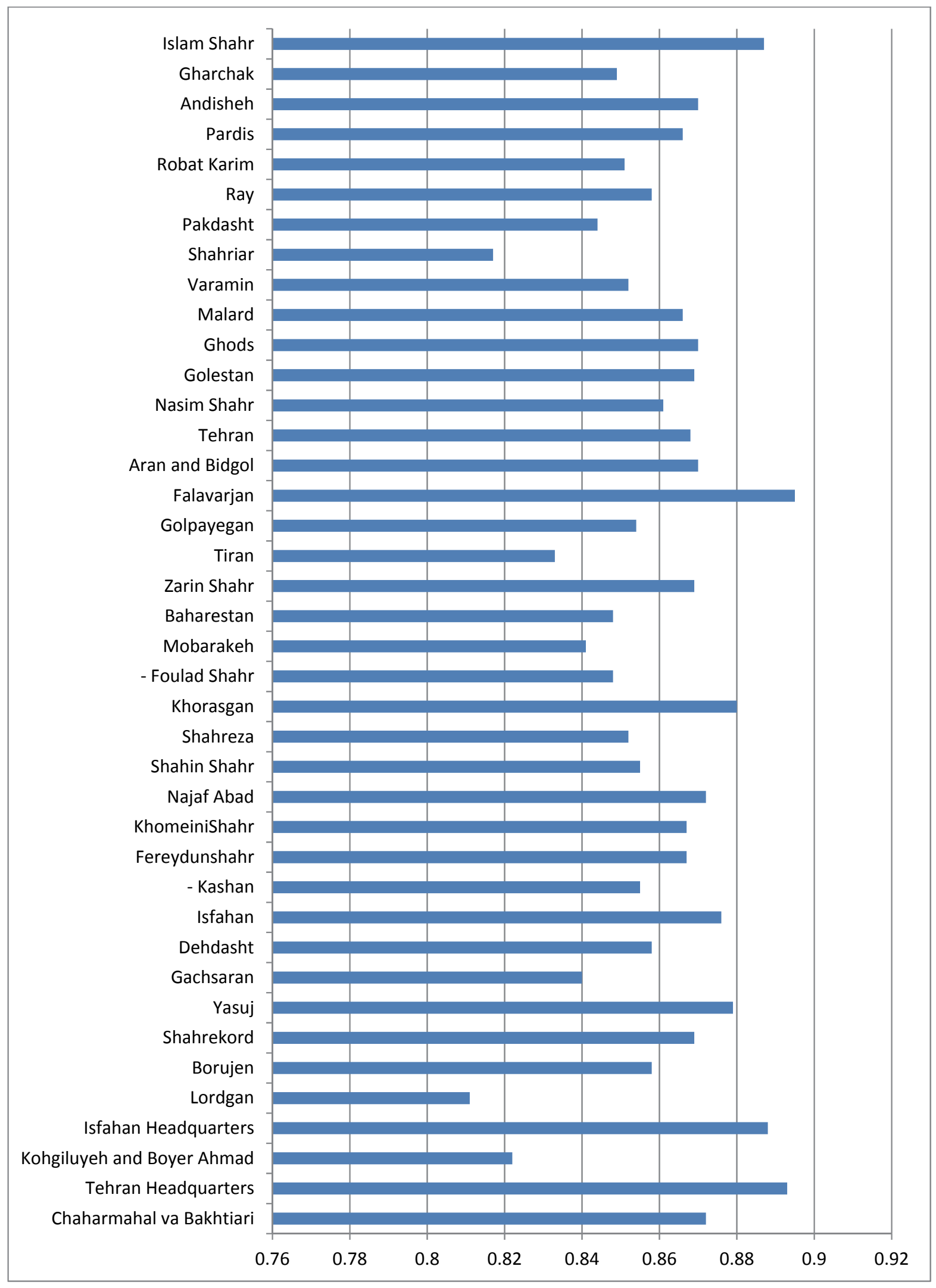

Fig. 3. Total performance based on the SCOR model using DEA 


\section{Discussion Conclusion}

Many researchers have considered dynamic capabilities as a process related to organizational ability to change in the form of their resources to respond to more efficient changes in their field of activities. Recently, dynamic capabilities and supply chain management have become important issues in scientific resources. There is also information on supply chain management in resources similar to the concept of dynamic capabilities. It is possible to create a more flexible and dynamic organization by combination of dynamic capabilities and supply chain management, so that the organization can easily and quickly adapt to new market trends and not be affected by market turbulence. This will lead to create a competitive advantage in the company among other participants in the market. In this paper, we have presented and empirical investigation to measure the relative efficiencies of oil distribution firms in Iran. The study has implemented DEA method with that adaptation of balanced scorecard perspectives to measure the performance of the units in a comprehensive method. The results have indicated that the network has performed relatively efficient since we did not detect any unit with low performance and most of the units have maintained relatively high scores.

\section{References}

Aydın, S. D., Eryuruk, S. H., \& Kalaoğlu, F. (2014). Evaluation of the performance attributes of retailers using the scor model and AHP: a case study in the Turkish clothing industry. Fibres \& Textiles in Eastern Europe.

Battese, G. E., \& Coelli, T. J. (1995). A model for technical inefficiency effects in a stochastic frontier production function for panel data. Empirical Economics, 20(2), 325-332.

Beamon, B. M. (1999). Measuring supply chain performance. International journal of operations \& production management, 19(3), 275-292.

Charnes, A., Clark, C. T., Cooper, W. W., \& Golany, B. (1984). A developmental study of data envelopment analysis in measuring the efficiency of maintenance units in the US air forces. Annals of operations Research, 2(1), 95-112.

Charnes, A., Cooper, W. W., Lewin, A. Y., \& Seiford, L. M. (Eds.). (2013). Data envelopment analysis: Theory, methodology, and applications. Springer Science \& Business Media.

Estampe, D., Lamouri, S., Paris, J.L, \& Djelloul, S.B. (2013). A framework for analyzing supply chain performance evaluation models. International Journal of Production Economics, 142, 247-258.

Georgise, F. B., Thoben, K. D., \& Seifert, M. (2012). Adapting the SCOR model to suit the different scenarios: a literature review \& research agenda. International Journal of Business and Management, 7(6), 2.

Gunasekaran, A., \& Ngai, E. W. (2004). Information systems in supply chain integration and management. European Journal of Operational Research, 159(2), 269-295.

Jagadesh, R. (2015). Performance assessment of global supply chains and moving towards optimization of efforts and challenges. International Journal of Recent Advances in Organizational Behaviour and Decision Sciences, 1 400-416.

Kaplan, R. S., \& Norton, D. P. (2001). Transforming the balanced scorecard from performance measurement to strategic management: Part I. Accounting horizons, 15(1), 87-104.

Kaplan, R. S., Robert, N. P. D. K. S., Davenport, T. H., Kaplan, R. S., \& Norton, D. P. (2001). The strategy-focused organization: How balanced scorecard companies thrive in the new business environment. Harvard Business Press.

Talluri, S., Narasimhan, R., \& Nair, A. (2006). Vendor performance with supply risk: A chance-constrained DEA approach. International Journal of Production Economics, 100(2), 212-222.

Mohamadi Janaki, D., Mirzazadeh, A., Mohamadi Janaki, M. (2019), Reducing barriers to the implementation of strategic management by providing improved strategies: Using fuzzy QFD applied to Petropars Company. International Journal of Industrial and Systems Engineering, 31(4), 535-557. 
Ntabe, E. N., LeBel, L., Munson, A. D., \& Santa-Eulalia, L. A. (2015). A systematic literature review of the supply chain operations reference (SCOR) model application with special attention to environmental issues. International Journal of Production Economics, 169, 310-332.

Piotrowicz, W., \& Cuthbertson, R. (2015). Performance measurement and metrics in supply chains: an exploratory study. International Journal of Productivity and Performance Management, 64(8), 10681091.

Ross, A., \& Droge, C. (2002). An integrated benchmarking approach to distribution center performance using DEA modeling. Journal of Operations Management, 20(1), 19-32.

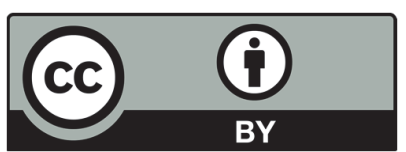

(C) 2019 by the authors; licensee Growing Science, Canada. This is an open access article distributed under the terms and conditions of the Creative Commons Attribution (CC-BY) license (http://creativecommons.org/licenses/by/4.0/). 